\title{
The Effect of Using Videoscribe as a Teaching Media on Writing Descriptive Text of the Tenth Grade Students of SMK YPSEI Palangka Raya
}

\author{
I Nyoman Trio Satya Sudana ${ }^{1 *}$, Ristati ${ }^{2}$, Tampung N. Saman ${ }^{3}$ \\ 1,2,3The Study Program of English Education, Faculty of Teacher Training and Education \\ University of Palangka Raya
}

\begin{abstract}
Learning Process during pandemic covid-19 has become harder for teacher and students. The learning process has to encourage, motivate, and stimulate the students so the learning process can be done effectively. This study aims to find out the effect of using videoscribe as a teaching media on writing descriptive text of the tenth grade students of SMK YPSEI Palangka Raya. The research subject was the tenth grade students of SMK YPSEI Palangka Raya. This Study is a quantitative method that using Randomized-Groups Pre-Test-Post-Test Control Group Design. The instrument that used was writing descriptive. The data were collected in several steps: pre-test, treatment, and post-test; the data were processed in several steps: collecting data, scoring, and calculating; data analysing was conducted using SPSS application including tests of data normality and tests of Hypothesis. The data analysing was conducted using Non-parametric tests on two paired samples which was Wilcoxon Sign Rank test. The result of this study conclude that the use of videoscribe as a teaching media has significant effect for the students in writing descriptive text.
\end{abstract}

Keywords: writing skill, descriptive text, videoscribe, teaching media

\section{INTRODUCTION}

English is an international language in the world. It is because there are about 350 million people around the world speaking English as their first language and more than 430 million people speaking it as their second language Wil (2018). As an international language, English is one of the most popular subjects to learn in every school in the world. In Indonesia, English is one of the most common subjects learned by students in school since they are in elementary school. The general purpose of learning English in school is to obtain a good understanding of the English language so the students will be able to communicate both orally and in the written form of English. To master those abilities, there are four skills of English that should be mastered: Listening, Speaking, Reading, and Writing.

Written English is the hardest skill to be mastered since writing is a process of discovering and organizing an idea, arranging them on paper, and reshaping and revising them Mayers (2005, as cited in Autila \& Theresia, 2018). In learning writing skills, there are some majors categories of writing that should be well known such as Narrative Writing, Descriptive Writing, Persuasive Writing, and Expository Writing. According to the curriculum 2013, writing skills in the tenth grade of Vocational High School consist of descriptive text, narrative text, and recount text.

\footnotetext{
*Corresponding author: inyomantrioss98@gmail.com

To cite this article: Sudana, I.N.T., Ristati, \& Saman, N.T. (2021). The Effect of Using Videoscribe as a Teaching Media on Writing Descriptive Text of the Tenth Grade Students of SMK YPSEI Palangka Raya. Ebony --- Journal of English Language Teaching, Linguistics, and Literature, 1 (1) 2021, pp. 10--21.
} 
According to the interview of the English teacher in SMK YPSEI Palangka Raya, the common problem faced by the tenth grade students of SMK YPSEI Palangka Raya was learning descriptive text. Descriptive text is a meaningful text that can inform the readers about the shape, sound, color, and taste related to the object of description.

Nowadays, students are facing more difficult problems in learning due to pandemic covid-19. During pandemic covid-19, the teaching and learning process becomes harder for both teachers and students. It is because the teaching and learning process is conducted online so the teachers and students are required to be adaptable to the new experience of the learning process.

Improving the students' ability in writing descriptive text during online learning can be done by using a teaching media that has the ability to encourage, motivate, and stimulate students; Teaching media means all tools that can be used by teachers to deliver material of learning. It can help students to understand the material easily and can increase their interest in the learning process. One of the teaching media that suitable for teaching descriptive text during online learning is VideoScribe. It is because VideoScribe has benefits such as memorable, fun, easy to use, and suitable for any topic; VideoScribe is a program developed by UK company Sparkol that can create whiteboard animations and explainer videos.

Furthermore, the use of VideoScribe as a teaching media has been conducted in a few research in Indonesian schools such as was done by Sessu et al. (2018) Entitled "The Effectiveness of Video Scribe in Teaching English at SMPN 1 Molawe Konawe Utara. And another research was done by Aryuntini et al. (2018) Entitled “Development of Learning Media Based on VideoScribe to Improve Writing Skill for Descriptive Text of English Language Study". The findings of those research showed that the VideoScribe successfully improved the students' ability in the subject learning.

Considering all the previous research and the good results, the researcher was interested to conduct a research about using VideoScribe as teaching to find out whether or not there was a significant effect on writing descriptive text of the tenth grade students of SMK YPSEI Palangka Raya.

There were some contributions from the previous research results to this research including research theory, research method, and the research findings that inspired and supported the researcher in conducting this research. The first contribution was from the first previous research; The researcher got that the use of learning media can help students improve their writing skills and foster student interests. Moreover, the use of VideoScribe as a teaching media from the study showed that there was a significant effect on the students writing skills of descriptive text. The second contribution was from the second previous research; The researcher got that there should be experimental and control groups in the experimental research so that the data collected from the experimental group which used VideoScribe as the teaching media can be compared to the control group which used the regular teaching media in the school. And the last contribution was from the findings of those previous studies that showed there was a significant effect on writing skill by using VideoScribe as a teaching media, it indicated that VideoScribe can be a good media for teaching that affects significantly on student's writing skill. Because of that, the researcher 
was interested to conduct a research about the use of VideoScribe as a teaching media on writing skill of descriptive text in different school.

\section{METHODS}

This research was based on a quantitative approach and the research is classified as a true experimental design because this research process was establishing cause-effect relationships between the variables (the independent variable) and (the dependent variable). Sugiyono (2017, as cited in AsikBelajar.com, 2018) states that true experimental design is divided into two categories. There are Post-Test-only control-group design and Pre-TestPost-Test control-group design. This research was using the Randomized-Groups Pre-TestPost-Test Control Group Design. It was intended to know whether or not the use of VideoScribe had a significant effect on students' writing descriptive text in the experimental group. The design of this research was described as follows:

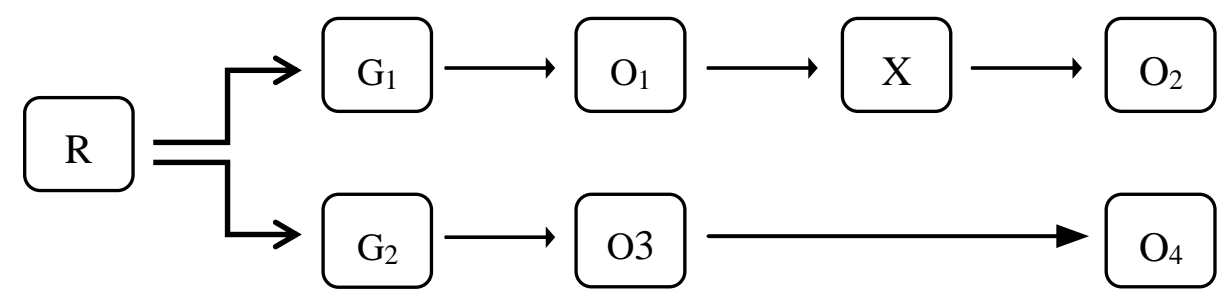

Figure 1. Randomized-Groups Pre-Test Post-Test Control Group Design

Where:

$\mathrm{R} \quad=$ Random Assignment

$\mathrm{G} 1=$ Experimental Group, the group that assigned to receive treatment

G2 = Control Group, the group assigned to receive no treatment, but the usual, standard treatment and conditions

$\mathrm{X}=$ Treatment (VideoScribe)

O1 = Observation of Experimental group before receiving treatment

$\mathrm{O} 2=$ Observation of Experimental group after receiving treatment

$\mathrm{O} 3=$ Observation of Control group before receiving no treatment

$\mathrm{O} 4=$ Observation of Control group after receiving no treatment

This research design consisted of two groups which were the experimental group and the control group. The experimental group was to be the group of the sample that received the treatment which was a VideoScribe as a teaching media to teach the descriptive text and the control group was to be the group that received no treatment but only the usual or standard treatment of the teaching process in SMK YPSEI Palangka Raya, which was using Microsoft PowerPoint as the teaching media.

In educational research, the population contains all members of the group to which the researcher wants to generalized the result of the research Toendan (2019). The target population of this research was the tenth-grade students of SMK YPSEI Palangka Raya in the academic year 2020/2021. The number of the population was 36 students from Manajemen Perkantoran and Tata Boga departments or classes; In SMK YPSEI Palangka Raya, those two classes had been joined together in learning English. So they were taught similar treatment at the same time. 
The sample was drawn by using simple random sampling that was done by random name picker from the website www.classtools.net. The sample was 32 students since there were a few students that less attending the learning activity and it based on on the 5\% significance level of 36 population. The sample was assigned randomly to the experimental and control groups as the number of 16 samples for each group using random name picker from the same website as used to conduct the random sampling technique.

This research was done for two months including Pretest, Treatments, and Posttest. The data collecting process was explained as follows:

1. The researcher found the data about the number of students in the tenth grade of SMK YPSEI Palangka Raya in the academic year 2020/2021 as the population of the research; The researcher used a simple random sampling technique to draw the sample from the target population; the researcher assigned the sample randomly into experimental and control group; the researcher coded the students' names into STD1, STD2, to STD16 for the experimental group; and STD17, STD18, to STD32 for the control group.

2. The researcher conducted a Pretest to know the students' prior ability in writing descriptive text. After that, The researcher delivered some treatments to the experimental and the control groups using different teaching media which was VideoScribe for the experimental group and PowerPoint Slides for the control group. Finally, the researcher conducted a posttest to know the improvement of the student's ability after delivered the treatments.

3. The data of this research were collected from the students' scores of writing descriptive text from the experimental group and control group through Pre-Test and Post-Test; the students' scores were converted to the data using a scoring rubric system of writing adapted from Brown (2007) that used by the English teacher in SMK YPSEI Palangka Raya. The Scoring Rubric system used are explained as follows:

Table 1. Scoring Rubric System Adapted from Brown (2007)

\begin{tabular}{|c|c|c|c|}
\hline Aspect & Score & Performance Description & Weight \\
\hline \multirow{4}{*}{$\begin{array}{l}\text { Content } \\
\text { (C) } \\
30 \% \\
\text {-Topic } \\
\text {-Details }\end{array}$} & 4 & $\begin{array}{l}\text { The topic is complete and clear and } \\
\text { the details are relating to the topic }\end{array}$ & \multirow{4}{*}{$3 x$} \\
\hline & 3 & $\begin{array}{l}\text { The topic is complete and clear but the } \\
\text { details are almost relating to the topic }\end{array}$ & \\
\hline & 2 & $\begin{array}{l}\text { The topic is complete and clear but the } \\
\text { details are not relating to the topic }\end{array}$ & \\
\hline & 1 & $\begin{array}{l}\text { The topic is not clear and the details are } \\
\text { not relating to the topic. }\end{array}$ & \\
\hline
\end{tabular}




\begin{tabular}{|c|c|c|c|}
\hline \multirow{4}{*}{$\begin{array}{l}\text { Organization }(\mathrm{O}) \\
20 \% \\
\text {-Identification } \\
\text {-Descriptions }\end{array}$} & 4 & $\begin{array}{l}\text { Identification is complete and } \\
\text { descriptions are arranged with proper } \\
\text { connectives. }\end{array}$ & \multirow{4}{*}{$2 \mathrm{x}$} \\
\hline & 3 & $\begin{array}{l}\text { Identification is almost complete and } \\
\text { descriptions are arranged with almost } \\
\text { proper connectives. }\end{array}$ & \\
\hline & 2 & $\begin{array}{l}\text { Identification is not complete and } \\
\text { descriptions are arranged with few } \\
\text { misuse of connectives. }\end{array}$ & \\
\hline & 1 & $\begin{array}{l}\text { Identification is not complete and } \\
\text { descriptions are arranged with misuse } \\
\text { of connectives. }\end{array}$ & \\
\hline \multirow{4}{*}{$\begin{array}{c}\text { Grammar } \\
(\mathrm{G}) \\
20 \%\end{array}$} & 4 & $\begin{array}{l}\text { Very few grammatical or agreement } \\
\text { inaccuracy. }\end{array}$ & \multirow{4}{*}{$2 \mathrm{x}$} \\
\hline & 3 & $\begin{array}{l}\text { Few grammatical or agreement } \\
\text { inaccuracy but not effect on meaning. }\end{array}$ & \\
\hline & 2 & $\begin{array}{l}\text { Numerous grammatical or agreement } \\
\text { inaccuracy. }\end{array}$ & \\
\hline & 1 & $\begin{array}{l}\text { Frequent grammatical or agreement } \\
\text { inaccuracy. }\end{array}$ & \\
\hline \multirow{4}{*}{$\begin{array}{c}\text { Vocabulary } \\
(\mathrm{V}) \\
15 \%\end{array}$} & 4 & Effective choice of word forms & \multirow{4}{*}{$1.5 \mathrm{x}$} \\
\hline & 3 & $\begin{array}{l}\text { Few misuses of vocabularies, word } \\
\text { forms, but not change the meaning }\end{array}$ & \\
\hline & 2 & $\begin{array}{l}\text { Limited range of confusing words and } \\
\text { word forms. }\end{array}$ & \\
\hline & 1 & $\begin{array}{l}\text { Very poor knowledge of words, word } \\
\text { forms, and not understandable. }\end{array}$ & \\
\hline \multirow{4}{*}{\begin{tabular}{l}
\multicolumn{1}{c}{ Mechanics } \\
\multicolumn{1}{c}{$(\mathrm{M})$} \\
$15 \%$ \\
-Spelling \\
-Punctuation \\
-Capitalization
\end{tabular}} & 4 & $\begin{array}{l}\text { It uses correct spelling, punctuation, } \\
\text { and capitalization. }\end{array}$ & \multirow{4}{*}{$1.5 \mathrm{x}$} \\
\hline & 3 & $\begin{array}{l}\text { It has an occasional error of spelling, } \\
\text { punctuation, and capitalization. }\end{array}$ & \\
\hline & 2 & $\begin{array}{l}\text { It has a frequent error in spelling, } \\
\text { punctuation, and capitalization. }\end{array}$ & \\
\hline & 1 & $\begin{array}{l}\text { It is dominated by errors of spelling, } \\
\text { punctuation, and capitalization. }\end{array}$ & \\
\hline \multicolumn{4}{|c|}{ Score $=\frac{3 \mathrm{C}+2 \mathrm{O}+2 \mathrm{G}+1.5 \mathrm{~V}+1.5 \mathrm{M}}{40} \times 100$} \\
\hline
\end{tabular}

Furthermore, the test of pretest and posttest that used to collect the data were taken from the Syllabus of English subject of the tenth grade students of SMK YPSEI Palangka Raya; the tests were instruction to write a simple descriptive text about family members. The tests were given in form of Google form due to online learning. The treatments were given to the 
experimental and control group; the treatment of the experimental group was VideoScribe as the teaching media in learning descriptive text; the treatment of the control group was given by usual treatments which were PowerPoint slides as the teaching media in learning descriptive text. The treatments were delivered by WhatsApp group since online learning during Pandemic Covid-19.

Since this research was based on a quantitative approach, it used a descriptive statistic technique for analyzing the data. The data analysis consisted of tests of data normality and test of statistics. The tests of data normality were for deciding the measures and statistical methods for data analysis; it was done in several steps including inputting the data into the SPSS application worksheet and conducting the analysis of tests of data normality in the Anayze menu which was Explore command to find the result of Lilliefors and Shapiro-Wilk method. And since the number of sample was less than 30 samples, the result of tests of data normality that can be used was from the Lilliefors analysis method. The result of tests of data normality showed that the data were not normally distributed. And because of that, the statistical method that was used was the nonparametric method which was the Wilcoxon Sign Rank test. This test was conducted to find the value of the test of statistic that was used to determine the Hypothesis Result; it consisted of inputting the data and conducting analysis in Analyze menu which was Nonparametric Test on 2 Paired samples.

\section{RESULTS}

The data of this research were collected from pretest and posttest scores from both experimental and control groups. The data were drawn from the scores using scoring rubric system of writing adapted from Brown (2007). The data that was drawn from pretest and posttest from experimental and control groups are explained as follows:

Table 2. Pre-test scores of the experimental group

\begin{tabular}{|c|c|c|c|c|c|c|c|}
\hline \multirow[b]{2}{*}{ No. } & \multirow[b]{2}{*}{$\begin{array}{l}\text { Student's } \\
\text { Code }\end{array}$} & \multicolumn{5}{|c|}{ Student Score } & \multirow[b]{2}{*}{$\begin{array}{c}\text { Total Score } \\
\text { Score }=\frac{A+B+C+D+E}{40} \times 100\end{array}$} \\
\hline & & $\underset{0}{\stackrel{\overrightarrow{0}}{0}}$ & 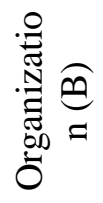 & 营 & $\begin{array}{l}\stackrel{\vec{\Xi}}{\vec{E}} \\
\stackrel{\tilde{J}}{0} \\
>\end{array}$ & 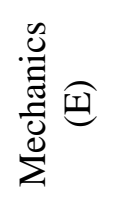 & \\
\hline 1 & STD 1 & 6 & 4 & 6 & 4.5 & 3 & 58.75 \\
\hline 2 & STD 2 & 9 & 6 & 6 & 4.5 & 4.5 & 75.00 \\
\hline 3 & STD 3 & 6 & 4 & 6 & 4.5 & 3 & 58.75 \\
\hline 4 & STD 4 & 6 & 4 & 6 & 4.5 & 3 & 58.75 \\
\hline 5 & STD 5 & 6 & 6 & 4 & 3 & 4.5 & 58.75 \\
\hline 6 & STD 6 & 6 & 4 & 4 & 4.5 & 3 & 53.75 \\
\hline 7 & STD 7 & 9 & 6 & 6 & 3 & 3 & 67.50 \\
\hline 8 & STD 8 & 9 & 6 & 6 & 4.5 & 3 & 71.25 \\
\hline 9 & STD 9 & 9 & 6 & 4 & 3 & 3 & 62.50 \\
\hline 10 & STD 10 & 9 & 4 & 4 & 3 & 3 & 57.50 \\
\hline 11 & STD 11 & 9 & 6 & 4 & 4.5 & 3 & 66.25 \\
\hline 12 & STD 12 & 6 & 4 & 6 & 3 & 3 & 55.00 \\
\hline 13 & STD 13 & 9 & 4 & 4 & 4.5 & 3 & 61.25 \\
\hline 14 & STD 14 & 6 & 6 & 4 & 3 & 3 & 55.00 \\
\hline
\end{tabular}




\begin{tabular}{llllllll}
\hline 15 & STD 15 & 9 & 4 & 6 & 4.5 & 3 & 66.25 \\
\hline 16 & STD 16 & 6 & 4 & 6 & 4.5 & 3 & 58.75 \\
\hline
\end{tabular}

Table 3. Pre-test scores of the control group

\begin{tabular}{|c|c|c|c|c|c|c|c|}
\hline \multirow[b]{2}{*}{ No. } & \multirow[b]{2}{*}{$\begin{array}{l}\text { Student's } \\
\text { Code }\end{array}$} & \multicolumn{5}{|c|}{ Student Score } & \multirow[b]{2}{*}{$\begin{array}{c}\text { Total Score } \\
\text { Score }=\frac{A+B+C+D+E}{40} \times 100\end{array}$} \\
\hline & & 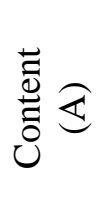 & . & 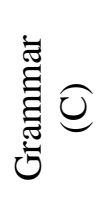 & 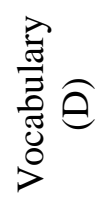 & 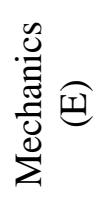 & \\
\hline
\end{tabular}

\begin{tabular}{cccccccc}
\hline 1 & STD 17 & 6 & 6 & 4 & 4.5 & 3 & 58.75 \\
\hline 2 & STD 18 & 6 & 4 & 4 & 4.5 & 4.5 & 57.50 \\
\hline 3 & STD 19 & 6 & 4 & 6 & 4.5 & 3 & 58.75 \\
\hline 4 & STD 20 & 9 & 4 & 6 & 4.5 & 4.5 & 70.00 \\
\hline 5 & STD 21 & 6 & 4 & 4 & 3 & 4.5 & 53.75 \\
\hline 6 & STD 22 & 6 & 4 & 6 & 4.5 & 3 & 58.75 \\
\hline 7 & STD 23 & 9 & 4 & 6 & 3 & 4.5 & 66.25 \\
\hline 8 & STD 24 & 6 & 6 & 4 & 4.5 & 3 & 58.75 \\
\hline 9 & STD 25 & 9 & 4 & 6 & 4.5 & 4.5 & 70.00 \\
\hline 10 & STD 26 & 9 & 4 & 6 & 3 & 4.5 & 66.25 \\
\hline 11 & STD 27 & 9 & 6 & 6 & 3 & 4.5 & 71.25 \\
\hline 12 & STD 28 & 6 & 4 & 6 & 4.5 & 3 & 58.75 \\
\hline 13 & STD 29 & 9 & 4 & 6 & 4.5 & 3 & 66.25 \\
\hline 14 & STD 30 & 6 & 4 & 4 & 4.5 & 3 & 53.75 \\
\hline 15 & STD 31 & 6 & 6 & 4 & 4.5 & 3 & 58.75 \\
\hline 16 & STD 32 & 6 & 4 & 4 & 4.5 & 3 & 53.75 \\
\hline & & & & & & &
\end{tabular}

Based on the scores of pretest of experimental and control group above, the researcher found that the scores of pretest from experimental and control group showed a various results; mostly the students' scores did not reach the standard score of KKM yet. The standard KKM of English subject in SMK YPSEI according to the English teacher was 70. However, there were 5 students who got score $\geq 70$ such as STD 2, STD 8, STD 20, STD 25, and STD 27.

Table 4. Post-test scores of the experimental group

\begin{tabular}{|c|c|c|c|c|c|c|c|}
\hline \multirow[b]{2}{*}{ No. } & \multirow[b]{2}{*}{$\begin{array}{l}\text { Student's } \\
\text { Code }\end{array}$} & \multicolumn{5}{|c|}{ Student Score } & \multirow[b]{2}{*}{$\begin{array}{c}\text { Total Score } \\
\text { Score }=\frac{A+B+C+D+E}{40} \times 100\end{array}$} \\
\hline & & 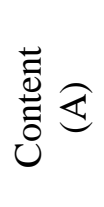 & 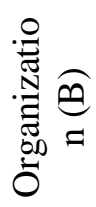 & 离 & 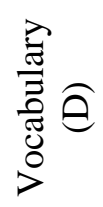 & 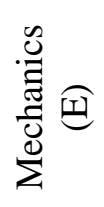 & \\
\hline 1 & $\begin{array}{l}\text { STD } 1 \\
\end{array}$ & 9 & 6 & 6 & 4.5 & 4.5 & 75.00 \\
\hline 2 & STD 2 & 9 & 6 & 6 & 4.5 & 6 & 78.75 \\
\hline 3 & STD 3 & 9 & 6 & 6 & 4.5 & 3 & 71.25 \\
\hline 4 & STD 4 & 9 & 6 & 6 & 4.5 & 4.5 & 75.00 \\
\hline 5 & STD 5 & 9 & 6 & 4 & 3 & 4.5 & 66.25 \\
\hline 6 & STD 6 & 9 & 6 & 6 & 4.5 & 3 & 71.25 \\
\hline
\end{tabular}




\begin{tabular}{cccccccc}
\hline 7 & STD 7 & 9 & 6 & 6 & 3 & 4.5 & 71.25 \\
\hline 8 & STD 8 & 9 & 6 & 6 & 4.5 & 4.5 & 75.00 \\
\hline 9 & STD 9 & 9 & 6 & 6 & 4.5 & 3 & 71.25 \\
\hline 10 & STD 10 & 9 & 6 & 6 & 3 & 4.5 & 71.25 \\
\hline 11 & STD 11 & 9 & 6 & 6 & 4.5 & 4.5 & 75.00 \\
\hline 12 & STD 12 & 9 & 6 & 6 & 4.5 & 3 & 71.25 \\
\hline 13 & STD 13 & 9 & 6 & 6 & 4.5 & 3 & 71.25 \\
\hline 14 & STD 14 & 9 & 6 & 6 & 4.5 & 4.5 & 75.00 \\
\hline 15 & STD 15 & 9 & 6 & 6 & 4.5 & 4.5 & 75.00 \\
\hline 16 & STD 16 & 9 & 6 & 6 & 4.5 & 3 & 71.25 \\
\hline
\end{tabular}

According to the scores of the posttest from the experimental group, they showed an improvement from the students' scores of the pretest to the students' scores of the posttest. Moreover, there were a few students that showed significant improvement in the scores of posttest such as STD 1, STD 2, STD 4, STD 8, STD 11, STD 14, and STD 15. Meanwhile, there was a student of STD 5 who showed an improvement but still did not achieve the standard score of KKM.

Table 5. Post-test scores of the control group

\begin{tabular}{|c|c|c|c|c|c|c|c|}
\hline \multirow[b]{2}{*}{ No. } & \multirow[b]{2}{*}{$\begin{array}{l}\text { Student's } \\
\text { Code }\end{array}$} & \multicolumn{5}{|c|}{ Student Score } & \multirow[b]{2}{*}{$\begin{array}{c}\text { Total Score } \\
\text { Score }=\frac{A+B+C+D+E}{40} \times 100\end{array}$} \\
\hline & & $\underset{0}{\stackrel{\overrightarrow{0}}{0}}$ & 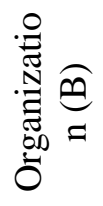 & $\underset{\Xi}{\tilde{\Xi}}$ & 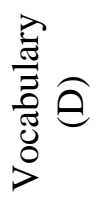 & 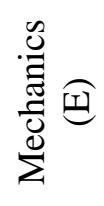 & \\
\hline 1 & STD 17 & 9 & 6 & 4 & 4.5 & 4.5 & 70.00 \\
\hline 2 & STD 18 & 9 & 4 & 6 & 4.5 & 4.5 & 70.00 \\
\hline 3 & STD 19 & 6 & 6 & 6 & 4.5 & 4.5 & 67.50 \\
\hline 4 & STD 20 & 9 & 6 & 6 & 4.5 & 4.5 & 75.00 \\
\hline 5 & STD 21 & 6 & 6 & 6 & 4.5 & 4.5 & 67.50 \\
\hline 6 & STD 22 & 9 & 4 & 6 & 4.5 & 4.5 & 70.00 \\
\hline 7 & STD 23 & 9 & 6 & 6 & 4.5 & 4.5 & 75.00 \\
\hline 8 & STD 24 & 6 & 6 & 6 & 4.5 & 4.5 & 67.50 \\
\hline 9 & STD 25 & 9 & 6 & 6 & 4.5 & 4.5 & 75.00 \\
\hline 10 & STD 26 & 9 & 6 & 6 & 4.5 & 4.5 & 71.25 \\
\hline 11 & STD 27 & 9 & 6 & 6 & 4.5 & 4.5 & 75.00 \\
\hline 12 & STD 28 & 6 & 6 & 6 & 4.5 & 4.5 & 67.50 \\
\hline 13 & STD 29 & 9 & 6 & 6 & 4.5 & 4.5 & 71.25 \\
\hline 14 & STD 30 & 6 & 6 & 6 & 4.5 & 4.5 & 67.50 \\
\hline 15 & STD 31 & 6 & 6 & 6 & 4.5 & 4.5 & 67.50 \\
\hline 16 & STD 32 & 9 & 4 & 4 & 4.5 & 4.5 & 65.00 \\
\hline
\end{tabular}

Based on the scores of the posttest from control group, they showed an improvement from the students' scores of the pretest to the students' scores of the posttest. Moreover, there were a few students of the control group who showed significant improvement in the scores of posttest such as STD 20, STD 23, STD 25, and STD 27. Meanwhile, there were some students who showed an improvement but still did not achieve the standard score of KKM; they are such as STD 19, STD 21, STD 24, STD 28, STD 30, STD 31, and STD 32. 
The data that were collected from the pretest and posttest of the experimental and control group were analyzed using SPSS application including the tests of data normality for deciding the measures and statistical methods for data analysis; test statistics to conclude the hypothesis result. The result of tests of data normality are showed in the following table.

Table 6. Test of data normality

Tests of Normality

\begin{tabular}{|c|c|c|c|c|c|c|c|}
\hline & \multirow{2}{*}{ Group } & \multicolumn{3}{|c|}{ Kolmogorov-Smirnov ${ }^{\mathrm{a}}$} & \multicolumn{3}{|c|}{ Shapiro-Wilk } \\
\hline & & Statistic & $\mathrm{df}$ & Sig. & Statistic & $\mathrm{df}$ & Sig. \\
\hline \multirow{4}{*}{$\begin{array}{l}\text { Student's } \\
\text { Score }\end{array}$} & $\begin{array}{l}\text { Pre-test } \\
\text { EXPERIMENTAL }\end{array}$ & 0.24 & 16 & 0. & 0.912 & 16 & 0.123 \\
\hline & $\begin{array}{l}\text { Post-test } \\
\text { EXPERIME }\end{array}$ & 0.267 & 16 & 0.003 & 0.849 & 16 & 0.013 \\
\hline & Pre-test CONTROL & 0.290 & 16 & 0.001 & 0.869 & 16 & 0.026 \\
\hline & Post-test CONTROL & 0.226 & 16 & 0.029 & 0.862 & 16 & 0.021 \\
\hline
\end{tabular}

a. Lilliefors Significance Correction

The result of tests of data normality can be drawn from the significant values (sig.) of the Lilliefors test since the number of sample was less than 30 samples. The analysis result can be drawn by comparing the significance values (sig.) of Liliefors analysis method to the level of significance at $5 \%(0.05)$.

According to the result of the analysis that was done by Liliefors, it shows that the significance values (sig.) of both pretest and posttest from experimental and control groups indicated that the data were not distributed normally. It was concluded by the result of data analysis which was all of the significance values (sig.) of the analysis process less than 0.05 which is the level of significance at $5 \%$.

Based on the explanation above, the researcher interpreted the result of data normality analysis as follows:

1. Pre-test of Experimental group (Group 1) $=$ sig. $0.014<0.05$. so, the data was not normally distributed.

2. Post-test of Experimental group (Group 2$)=$ sig. $0.003<0.05$. so, the data was not normally distributed.

3. Pre-test of Control group (Group 3$)=$ sig. $0.001<0.05$. so, the data was not normally distributed.

4. Post-test of Control group (Group 4$)=$ sig. $0.029<0.05$. so, the data was not normally distributed.

Since the data were not normally distributed, the test of statistics was conducted by Nonparametric test which was the Wilcoxon Sign Rank test method. It was an analysis for determining the result of hypothesis testing when the data were not normally distributed. The result of this analysis are presented in the following table. 


\begin{tabular}{lcc}
\hline \multicolumn{3}{c}{ Test Statistics $^{\mathbf{a}}$} \\
\hline $\begin{array}{c}\text { Post-test Experimental - } \\
\text { Pre-test Experimental }\end{array}$ & $\begin{array}{c}\text { Post-test control - Pre- } \\
\text { test control }\end{array}$ \\
\hline $\mathbf{Z}$ & $\mathbf{- 3 . 5 2 4}$ & $\mathbf{- 3 . 5 3 7 ^ { \mathbf { b } }}$ \\
\hline Asymp. Sig. (2-tailed) & $\mathbf{0 . 0 0 0}$ & $\mathbf{0 . 0 0 0}$ \\
\hline a. Wilcoxon Signed Ranks Test & & \\
\hline b. Based on negative ranks. & & \\
\hline
\end{tabular}

Due to this research aims to find out the effect of using VideoScribe as a teaching media, the researcher only focuses on the result of the experimental group. It is because the experimental group was the group that had been given VideoScribe as the treatment.

The result of data analysis can be concluded by comparing the value of Asymp. Sig. (2-tailed) which is 0.000 to the level of significance at $5 \%(0.05)$. The result showed that the value of Asymp. Sig. (2-tailed) was less than 0.05 which means that the Alternative hypothesis was accepted and the Null hypothesis was rejected.

\section{DISCUSSION}

This research was based on a quantitative approach and the research is classified as a true experimental design. The aim of this research was to find out whether or not the use of VideoScribe as teaching media affects significantly on writing descriptive text of the tenthgrade students of SMK YPSEI Palangka Raya in the academic year 2020/2021.

The research data were from students' scores of pretest and posttest of the experimental and the control groups; the students' scores of pretest showed the prior knowledge of the students and the scores of posttest showed the improvement of the students' scores after the researcher delivered the treatments. The researcher analyzed the data of the result of pre-test and post-test from both experimental and control group by SPSS application using Wilcoxon Sign Rank test method because the data which had been calculated by Lilliefors Test were not distributed normally.

The result of data analysis using the Wilcoxon Sign Rank test method showed that the value of Asymp. Sig. (2-tailed) $=0.000$ for Post-test Experimental - Pre-test Experimental and the value of Asymp. Sig. (2-tailed) $=0.000$ for Post-test Control - Pre-test Control; and according to those values, the hypothesis of this research can be drawn by comparing these values to the value of the level of significance at 5\% (0.05). Since this research aimed to find out the effect of VideoScribe as a teaching media, the finding of the analysis was only focused on the result of pretest and posttest of the experimental group because it was the group that was given treatments by using VideoScribe. The result of the data analysis showed that the Alternative Hypothesis (Ha) was accepted and the Null Hypothesis (H0) was rejected. It means that there was a significant effect of using VideoScribe as a Teaching Media on Writing Descriptive Text of the Tenth Grade Students of SMK YPSEI Palangka Raya in the academic year 2020/2021. 
Considering the finding of this research, the researcher concludes that the VideoScribe can be a good teaching media in nowadays due to the functions and the facilities that presented by the Sparkol Company in their theory. In addition, it is also considering the findings of some research that indicate the VideoScribe has given a significant effect on students' writing skills.

Finally, According to the research findings, it can be concluded that the research findings had similarities to the previous research findings which the use of Videoscribe affected significantly on the students writing descriptive text; moreover, this research was also conducted on the similar subject of the previous research so that there was a probability of achieving the similar result. In addition, this research findings supported the previous research results since this research showed similar findings; and this research also contributed to the education research for a good result of using Videoscribe as a teaching media. In the future, this teaching media hopefully can be used to achieve the students' improvement of writing descriptive text.

\section{CONCLUSION}

This research aims to find out the effect of using VideoScribe as a teaching media on writing descriptive text of the tenth grade students of SMK YPSEI Palangka Raya. The population of this research was tenth grade students consisted of Manajemen Perkantoran and Tata Boga; the sample was drawn from the population using simple random sampling that was done by random name picker from the website www.classtools.net. The data of this research were the students' scores of pretest and posttest from the experimental and control groups that were drawn by scoring rubric system of writing adapted from Brown (2007. The tests used for collecting the students' scores were taken from Syllabus of English subject of the tenth grades students of SMK YPSEI Palangka Raya and given in form of Google form. The data analysis was conducted by SPSS application including tests of data normality and tests of statistics. The result of the analysis that was conducted by Liliefors analysis method showed that the data were not normally distributed; and according to the result of tests statistics, it can be concluded that the Alternative hypothesis was accepted which means there was a significance effect of using VideoScribe as a teaching media on writing descriptive text of the tenth grade students of SMK YPSEI Palangka Raya. Finally, this research findings accomplished similar findings of the previous research and it supported the previous research which found that the use of VideoScribe as a teaching media affected significantly on the students writing skill of descriptive text; these findings contributed to the education research since there was a good finding that can be used to improve the teaching process of English education in the future.

\section{REFERENCES}

Al Arif, T. (2020, February). The Influences of Audio Visual Media and Vocabulary Mastery towards English Learning Achievement of EFL University Students. Journal of English for Academic, 7(1), 58. doi:https://doi.org/10.25299/jshmic.2020.vol7(1).3905 
Aryuntini, N., Astuti, I., \& Yuliana, Y. G. (2018, September). Development of Learning Media Based on VideoScribe to Improve Writing Skill for Descriptive Text of English Language Study. Journal of Education, Teaching and Learning, 3(2), 187194. Retrieved January 12, 2021, from https://journal.stkipsingkawang.ac.id/index.php/JETL/article/view/746

AsikBelajar.com. (2018, August 3). 2 Macam Desain True Experimental Menurut Sugiyono. Retrieved March 20, 2021, from AsikBelajar.com: https://www.asikbelajar.com/2-macam-desain-true-experimental-menurutsugiyono/

Autila, R., \& Theresia, M. (2018). Improving Students' Writing Skill of Recount Text Through Diary Writing and Peer Editing Technique. Proceedings of ISELT FBS Universitas Negeri Padang, 6. Retrieved February 27, 2021, from http://ejournal.unp.ac.id/index.php/selt/article/view/100163

Bouchrika, I. (2020, December 23). A Guide to the Different Types of Writing. Retrieved February 21, 2021, from Guide2Research: https://www.guide2research.com/research/guide-to-the-different-types-of-writing

Course, B. (2017, December 12). Descriptive Text; Definition, Generic Structures, Purposes, Language Features. Retrieved January 23, 2021, from British Course: http://britishcourse.com/descriptive-text-definition-generic-structures-purposeslanguage-features.php

Sessu, A., Sahlan, \& Laepe, A. (2018). The Effectiveness Of Video Scribe In Teaching English At SMPN 1 Molawe Konawe Utara. Journal of Language Education and Educational Technology, 3(1). Retrieved February 2021, from http://ojs.uho.ac.id/index.php/JLEET/article/view/6666

Sparkol. (2021). Whiteboard animation. Retrieved February 22, 2021, from VideoScribe: https://www.videoscribe.co/en/whiteboard-animation

Toendan, W. H. (2019). True Experimental Designs. In W. H. Toendan, Research Methodology. Retrieved February 27, 2021

Wil. (2018). How English Became the Global Language. Retrieved December 22, 2020, from English Live: https://englishlive.ef.com/blog/english-in-the-realworld/english-became-global-language/ 